\title{
STRUCTURAL CHANGES AND DEGRADATION OF RED LATOSOLS UNDER DIFFERENT MANAGEMENT SYSTEMS FOR 20 YEARS ${ }^{(1)}$
}

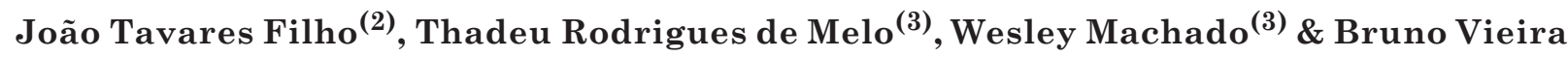 \\ Maciel $^{(4)}$
}

\begin{abstract}
SUMMARY
Soils are the foundation of terrestrial ecosystems and their role in food production is fundamental, although physical degradation has been observed in recent years, caused by different cultural practices that modify structures and consequently the functioning of soils. The objective of this study was to evaluate possible structural changes and degradation in an Oxisol under different managements for 20 years: no-tillage cultivation with and without crop rotation, perennial crop and conventional tillage, plus a forested area (reference). Initially, the crop profile was described and subsequently, 10 samples per management system and forest soil were collected to quantify soil organic matter, flocculation degree, bulk density, and macroporosity. The results indicated structural changes down to a soil depth of $50 \mathrm{~cm}$, with predominance of structural units $\Delta \mu$ (intermediate compaction level) under perennial crop and no-tillage crop rotation, and of structural units $\Delta$ (compacted) under conventional tillage and no-tillage. The soil was increasingly degraded in the increasing order: forest $=>$ no-tillage crop rotation $=>$ perennial crop $=>$ no-tillage without crop rotation $=>$ conventional tillage. In all managements, the values of organic matter and macroporosity were always below and bulk density always above those of the reference area (forest) and, under no-tillage crop rotation and perennial crop, the flocculation degree was proportionally equal to that of the reference area.
\end{abstract}

Index terms: crop profile, soil physical properties, organic matter, soil quality.

(1) Received for publication on August 20, 2013 and approved on May 7, 2014.

(2) Associate Professor C, State University of Londrina (Universidade Estadual de Londrina - UEL). Rodovia Celso García Cid, Km 380, Campus Universitário. Caixa Postal 10011. CEP 86057-970 Londrina (PR), Brazil. E-mail: tavares@uel.br

(3) Post-Graduate Student in Agronomy, UEL. E-mail: thadeurodrigues@hotmail.com,w.machado@agronomo.eng.br

(4) Graduate Student in Agronomy, UEL. E-mail: brunov_m@hotmail.com 


\title{
RESUMO: MUDANÇAS ESTRUTURAIS E DEGRADAÇÃO DE ATRIBUTOS DE LATOSSOLO VERMELHO SUBMETIDO A DIFERENTES MANEJOS POR 20 ANOS
}

\begin{abstract}
O solo integra os ecossistemas terrestres e o papel dele na produção de alimentos é essencial, embora nos últimos anos tenha se constatado sua degradação física em razão das diferentes práticas culturais utilizadas que modificam sua estrutura e, consequentemente, seu funcionamento. $O$ objetivo deste trabalho foi avaliar possíveis mudanças estruturais, bem como a degradação de Latossolo Vermelho submetido a diferentes manejos por 20 anos. As avaliações foram realizadas em diferentes manejos: semeadura direta com e sem rotação de culturas; cultura perene; e preparo convencional, além de uma área de mata (referência). Inicialmente, fez-se a descrição do perfil cultural e, na sequência, coletaram-se 10 amostras de solo em cada manejo considerado e sob mata nativa para quantificar o teor de matéria orgânica, o grau de floculação, a densidade e a macroporosidade do solo. Os resultados indicaram mudanças estruturais até $50 \mathrm{~cm}$ de profundidade com predomínio de unidades estruturais $\Delta \mu$ (nivel intermediário de compactação) nos manejos cultura perene e semeadura direta com rotação de culturas e unidades estruturais $\Delta$ (compactado), nos manejos preparo convencional e semeadura direta. A degradação do solo, da menor para a maior, ocorreu na seguinte ordem: Mata => semeadura direta com rotação de culturas => cultura perene $=>$ semeadura direta sem rotação de culturas $=>$ preparo convencional. Em todos os manejos, os valores de matéria orgânica e macroporosidade sempre foram abaixo; a densidade do solo, sempre acima dos valores de referência (mata); e o grau de floculação, nos manejos semeadura direta com rotação de culturas e cultura perene, foi proporcionalmente igual ao valor de referência (mata).
\end{abstract}

Termos de indexação: perfil cultural, propriedades físicas do solo, matéria orgânica, qualidade de solo.

\section{INTRODUCTION}

Soils play a vital role as the foundation of terrestrial ecosystems and are fundamental in food production. However, soil degradation has recently become a major environmental problem. In the State of Paraná, the Red Latosol is one of the richest and most productive soil types for grain production for Brazilian domestic and export markets (Tavares Filho et al., 2010; 2012). However, the intensive soil use with agricultural technologies and a wide range of management and agricultural practices has resulted in soil physical degradation and structural changes, e.g., the formation of compacted layers (Collares et al., 2006; Portella et al., 2012; Llanillo et al., 2013; Calegari et al., 2013). These changes can cause damage, including the loss of soil pores, leading to reduced infiltration capacity, water availability, and aeration and increased root penetration resistance, affecting crop yields and intensifying soil erosion processes (Tavares Filho et al., 2012; Calegari et al., 2013).

Soil management systems (of any type) are designed to create or maintain favorable physical conditions for crop cultivation. The resulting changes in the soil structure can be more or less intense, according to the adopted management system. Generally, more intense soil management systems cause major soil structural changes, unlike no-tillage systems, which barely affect the soil structure, because the soil is not disturbed (Carpenedo \&
Mielniczuk, 1990; Tavares Filho et al., 1999, 2001, 2012; Neves et al., 2003; Calegari et al., 2006; Llanillo et al., 2006; Ralisch et al., 2008; Rós et al., 2014). However, the absence of soil disturbance together with intensified land use exposes the soil to heavy machinery traffic, which alters the soil structural quality and results in increased compaction when moisture conditions are inadequate (Collares et al., 2006; Tavares Filho et al., 2012; Calegari et al., 2013).

According to Leprun (1994), sound and applicable scientific data are important for the sustainable cultivation of certain soil types. Increasing production requirements and a commitment to sustainable development respecting the environment are rarely compatible with the complex soil ecosystems found in tropical regions and particularly in Brazil. Thus, quantifying soil quality is not easy. For example, soil quality depends on the intrinsic soil properties, on soil - ecosystem interactions and on the priorities of land use, which are influenced by socioeconomic and political aspects (Costa et al., 2006).

The often-repeated idea that soil physical degradation results from different agricultural practices that modify its structure and function is considered here. The objective of this study was to evaluate possible structural changes and the degradation in a Red Latosol treated with different management practices for 20 years. 


\section{MATERIAL AND METHODS}

\section{Study area}

The study area is located in Londrina in northern Paraná, Brazil (between $23^{\circ} 08^{\prime} 47^{\prime \prime}$ and $23^{\circ} 55^{\prime} 46^{\prime \prime} \mathrm{S}$, and $50^{\circ} 52^{\prime} 23^{\prime \prime}$ and $51^{\circ} 19^{\prime} 11^{\prime \prime} \mathrm{W} ; 603 \mathrm{~m}$ asl). According to the Köppen classification, the dominant climate in this region is humid subtropical $\mathrm{Cfa}$ (IAPAR, 2000). The soil was classified as a dystrophic Red Latosol with a very clayey texture (Table 1) and basalt origin. The gently sloping relief in the study area had a declivity of approximately 6-8 in the upper third of the slopes in all study plots (1 ha). The different management practices were evaluated (Table 1) as well as native forest soil, which was used as control (Co) treatment of the natural soil structure.

The entire area, formerly covered with native forest, was cleared in the 1940s to plant coffee until 1975. After 1975, coffee was replaced by grain crops (soybean, maize, wheat) under conventional tillage (CT). In 1983, $\mathrm{CT}$ was replaced by no-tillage systems.

A long-term experiment was installed in the upper third of the slope, where 1 ha plots were cultivated with no-tillage crop rotation (NTR), no-tillage without crop rotation (NT), CT and perennial crop (PC) after plowing, harrowing and leveling the soil. These areas were chosen for having the same soil type as native forest $(\mathrm{C})$ area and for representing soil management practices that are still common in northern Paraná.

\section{Crop profile}

Two trenches (depth $1.00 \mathrm{~m}$, width $0.80 \mathrm{~m}$, length $1.00 \mathrm{~m}$ ) were dug in the selected areas to represent each management system. The soil structure in each trench was characterized by the crop profile method described by Gautronneau \& Manichon and modified by Tavares Filho et al. (1999). This method is a diagnostic method that is particularly suited for studying the evolution of soil structure in cultivated soils under different management systems in tropical areas.

Initially, the horizontal distribution (mode of the soil structural unit organization - MOrgs) was characterized according to the observed soil continuity or fissures (Level 1 classification; Table 2). This process allowed the identification of anthropized macro layers with structural discontinuities and homogeneous morphologies. The anthropized macro layers consisted of structural units that were not bound to each other (individual) or pulverized (loose soil), which were classified as L (loose). Well-bonded structural units were classified as C (continuous), and the anthropized layers where the structural units were separated by fissures that were easily visible to the naked eye were classified as F (fissured). Anthropized layers with laminar structures were classified as Z. Soil structures resulting from macrofauna activity consisted of small loose aggregates classified as Biol.L (biological).
Level 2 (Table 2) classifies the internal state of the structural units (ISs) that constitute each anthropized layer. The IS is evaluated after "breaking" and analyzing the aggregate shape (polyhedral angular/ subangular), the aggregate size [small (sa - 1 to 5 $\mathrm{cm}$ ), medium (ma - 6 to $10 \mathrm{~cm}$ ) and large clumps (lc $>10 \mathrm{~cm}$ )], the roughness, the porosity and the presence of roots. If the exposed area of the structural units is coarse with visible porosity, a level of aggregation (microaggregation) is good, with root colonization and no signs of compaction, and IS is classified as " $\mu$ ". If the exposed area is flat, smooth and compacted with no visible porosity and with little or no root colonization, the IS is classified as " $\Delta$ ". The ISs with intermediate compaction are classified as " $\Delta \mu$ " or " $\mu \Delta$ " (Tavares Filho et al., 1999). These classes combine the two classification levels that constitute the morphologically homogeneous structural units (MHUs) (Tamia et al., 1999).

\section{Sampling and physical analysis}

After describing the soil profile with regard to the MOrg and ISs, the different MHUs were determined and 10 disturbed and undisturbed samples were collected randomly from the $0-50 \mathrm{~cm}$ soil layer in each management system and from native forest. These samples were analyzed to quantify the organic matter $(\mathrm{OM})$ content, bulk density $(\mathrm{Bd})$, total porosity and soil macroporosity (Ma), according to the methods of Embrapa (1997). The Bd was measured using the volumetric ring method with an internal volume of $50 \mathrm{~cm}^{3}$. The content of clay dispersed in water was measured by the pipette method without dispersant, and the flocculation degree (FD) by the procedures established by Embrapa (1997).

\section{Data analysis}

Statistical analysis was performed with the statistical package SAS/STAT. Data were analyzed according to the field/trench replications. The data were grouped in morphologically homogeneous layers and for management systems (Figure 1), for depths between 0 and $50 \mathrm{~cm}$, and subjected to Tukey's test at 1 and $5 \%$. Next, to compare the physical soil quality in an integrated manner for the different soil management systems, radial graphs were constructed as described by Costa et al. (2006) and Araújo et al. (2007). The values found for the soils under native forest were interpreted as indicating good soil physical quality and were used as reference values representing native forest in a balanced ecosystem.

\section{RESULTS AND DISCUSSION}

\section{Evaluation of the soil morphology}

The soils were evaluated by the crop profile method, by comparing the structures in the soil profiles under 
Table 1. Management practices, years of management, land use, soil clay content, and particle density (Pd) in the 0-50 cm layer of a Red Latosol

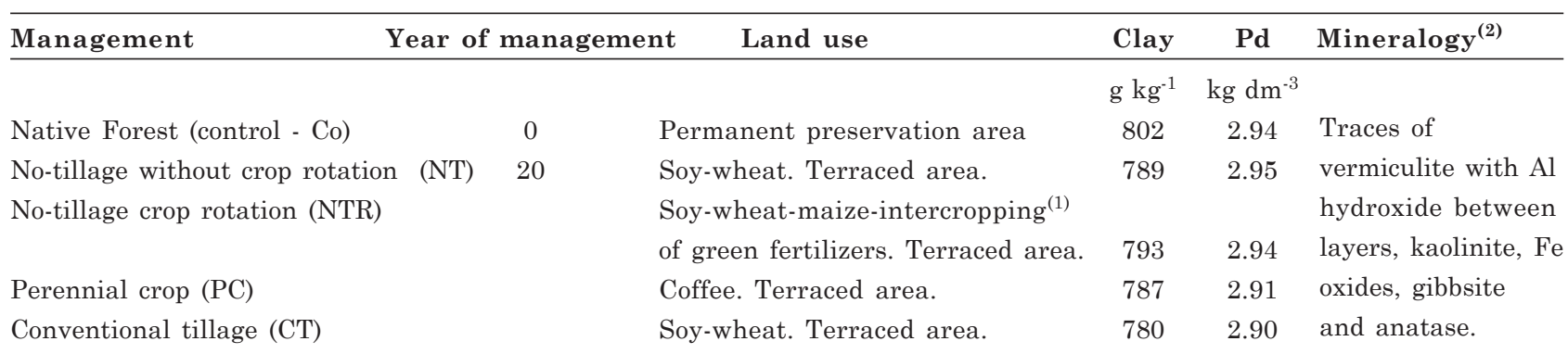

(1) Intercropping of black oat (Avena strigosa) + hairy vetch (Vicia villosa) and + white radish (Raphanus sativus) for residue incorporation into the soil. ${ }^{(2)}$ X-ray diffractograms made at the French Agronomic Institute (INRA - Versailles) of the nonferrous B wc horizon clay fraction that was saturated with $\mathrm{Mg}, \mathrm{Mg}+$ ethylene glycol and $\mathrm{K}$ heated to $350{ }^{\circ} \mathrm{C}$ and $550{ }^{\circ} \mathrm{C}$.

the different land use and management types and the control (Co). Figure 1 shows the crop profile design of the native forest area $(\mathrm{Co})$. In this profile, two MOrgs were observed, including the continuous organization mode C (0-100 cm depth) with well-bound structural units, a high level of aggregation (microaggregation), visible high porosity, abundance of roots as well as MHU (Cou) with biological activity (Biol.L) and IS of $\mu$ (uncompacted).

In the crop profiles (Figure 1: PC, CT, NT, and NTR), different MOrgs and ISs were observed after 20 years of the same management practice. In the profile of the area cultivated with PC, the following two MOrgs were observed: First, a cracked and fragmented organization mode $\mathrm{F}(0 \pm 45 \mathrm{~cm}$ depth), where the structural units consist of $6-10 \mathrm{~cm}$ aggregates and polyhedral subangular clumps $>10$ $\mathrm{cm}$ separated by cracks (fissures) with root development in the cracks. Second, a continuous organization mode $\mathrm{C}(> \pm 45 \mathrm{~cm}$ deep) was observed with well-bound structural units and the presence of roots, Biol.L and two ISs, $\Delta \mu$ (intermediate compaction level, between $0-45 \mathrm{~cm}$ deep) and $\mu$ (uncompacted, below $\pm 45 \mathrm{~cm}$ deep), forming two MHUs (F $\Delta \mu$ and $\mathrm{C} \mu$ ).

In the area with CT, the following three MOrg's were observed: First, a free fragmented organization mode $\mathrm{L}(0 \pm 20 \mathrm{~cm}$ deep $)$, most likely the product of soil disturbance, composed of structural units (6-10 $\mathrm{cm}$ aggregates and angular polyhedral clumps $>10$ $\mathrm{cm}$ ) with no adhesion and the presence of loose earth in-between with roots. Second, a continuous organization mode $\mathrm{C}(> \pm 20 \mathrm{~cm})$ with well-bound structural units, absence of roots and two ISs, $\Delta$ (compacted between $0 \pm 40 \mathrm{~cm}$ ) and $\mathrm{m}$ (uncompacted, below $\pm 40 \mathrm{~cm}$ deep), forming three MHUs (Lmt $\Delta ; \mathrm{C} \Delta$ and $\mathrm{C} \mu$ ). Two MOrg's were found in the profile of the $\mathrm{NT}$ area. First, the cracked and fragmented organizational mode $\mathrm{F}(0 \pm 55 \mathrm{~cm})$ was observed, in which the structural units (angular polyhedral clumps $>10 \mathrm{~cm}$ ) were separated by cracks (fissures) and root development occurred mainly in the cracks. Second, a continuous organization mode $\mathrm{C}(> \pm 55 \mathrm{~cm}$ deep) was observed with well-bound structural units, few roots, and two ISs, $\Delta$ (compacted between $0 \pm 55 \mathrm{~cm}$ ) and $\mu$ (uncompacted, below $\pm 55 \mathrm{~cm}$ ), which formed two MHUs (F $\Delta$ and $\mathrm{C} \mu$ ).

The profile of the area under NTR showed three MOrgs: First, a cracked and fragmented organization mode $\mathrm{F}(0 \pm 55 \mathrm{~cm}$ deep), where structural units (6-10 $\mathrm{cm}$ aggregates and polyhedral subangular clumps $>$ $10 \mathrm{~cm}$ ) were separated by cracks (fissures) with root development mainly in the cracks. Second, a continuous organization mode was observed C (>50 cm) with wellbound structural units, presence of roots and Biol.L, and two ISs, $\Delta \mu$ (intermediate compaction level, 0 to $\pm 50 \mathrm{~cm}$ deep) and $\mu$ (uncompacted, below $\pm 50 \mathrm{~cm}$ ), forming two MHUs $(\mathrm{F} \Delta \mu$ and $\mathrm{C} \mu)$.

The $(\mathrm{C} \mu \mathrm{MHU})$ results indicated that the soil profile under native forest had characteristics of a Red Latosol (i.e., structural organization consisting of small stable granular aggregates that form a rich network of stacked pores). Intra-aggregate porosity mainly occurred in the form of channels, most likely due to Biol.L and root development. When the different production management systems (PC, CT, NT and NTR) were initiated, stable granular aggregates $(\mathrm{MHU} \mathrm{C} \mu$ ) only occurred at depths of $40-50 \mathrm{~cm}$ (according to the considered management system), indicating structural changes (anthropization) to this depth, where the transition to non-anthropized horizons begins.

These results confirmed those of Neves et al. (2003), Portella et al. (2012) and Llanillo et al. (2013) and showed that the studied management systems result in soil structure differences. Conventional tillage with one plowing, one or two harrowings (depending on the year and need) and NT promoted important changes in the soil structure between 0 and $\pm 50 \mathrm{~cm}$ deep, compared to the soils under native forest and other management systems. This finding indicated a lower soil quality due to the formation of structural units with a compacted IS $(\Delta)$. This lower soil quality can 
result in soil pore loss and changes in infiltration rates, water availability, aeration and root penetration in the soil, which affect crop yields and induce erosion (Araújo et al., 2007; Collares et al., 2006; Tavares Filho et al., 2012; Portella et al., 2012; Llanillo et al., 2013).
In contrast, the structural changes described in the PC and NTR profiles are less harmful to root growth due to the formation of structural units with an IS of $\Delta \mu$ (ongoing compaction process), pores formed by decomposing roots and soil fauna (described in two profiles and in the soil under native forest) and to

Table 2. Mode of organization and internal state of the structural units(1) determined by the crop profile method

\begin{tabular}{|c|c|c|}
\hline Level of analysis & Symbol & Description \\
\hline \multirow[t]{4}{*}{1 (MOrg.) } & L or Biol.L & $\begin{array}{l}\text { Fragmented soil, consisting of loose, pulverized earth and aggregates of varying } \\
\text { sizes }(0-10 \mathrm{~cm}) \text { with no cohesion, common on the surfaces of tilled soils or in areas of } \\
\text { biological activity. Large numbers of roots can occur, with branching in all directions. } \\
\text { Stability in water and dry cohesion between the aggregates does not occur, but the } \\
\text { stability and cohesion of aggregates can be greater. Porosity is abundant to the } \\
\text { naked eye. }\end{array}$ \\
\hline & $\mathrm{F}$ & $\begin{array}{l}\text { Fragmented with large numbers of cracks (fissures) in all directions that form clumps } \\
\text { of varying sizes (greater than } 5 \mathrm{~cm} \text { ). The roots preferentially grow in the cracks and } \\
\text { the porosity is mainly due to the cracks. }\end{array}$ \\
\hline & $\mathrm{C}$ & $\begin{array}{l}\text { The structural units are well-bound, producing a very homogeneous structure, which } \\
\text { makes the separation of aggregates difficult. Roots may or may not be present, } \\
\text { porosity results essentially from the stacking of particles and/or aggregates, which } \\
\text { have circular cavities and/or tubular pores. }\end{array}$ \\
\hline & $\mathrm{Z}$ & $\begin{array}{l}\text { Laminar structure, compact. When present, the roots are sinuous and flat with } \\
\text { horizontal growth and without ramifications }\end{array}$ \\
\hline \multirow[t]{3}{*}{2 (ISs) } & $\mu$ & $\begin{array}{l}\text { Internal state of the structural units that were characterized by a sub-angular } \\
\text { polyhedral structure (without signs of compaction), porosity easily visible to the } \\
\text { naked eye, with rough rupture surfaces and little dry cohesion. Roots can occur } \\
\text { within and between aggregates and are well branched without deformation and } \\
\text { with vertical orientation. }\end{array}$ \\
\hline & $\Delta$ & $\begin{array}{l}\text { State of the structural units characterized by the angular polyhedral structure due } \\
\text { to strong external pressure (compaction signs), little or no porosity visible to the } \\
\text { naked eye. Roots, when present, have few or no branches, are deformed and have } \\
\text { vertical orientation hampered by compaction. Rupture surfaces are smooth and dry } \\
\text { cohesion is very high. }\end{array}$ \\
\hline & $\Delta \mu$ & $\begin{array}{l}\text { Intermediate compaction level, with internal state characteristics of the MHU between } \\
\Delta \text { and } \mu \text {. }\end{array}$ \\
\hline
\end{tabular}

(1) According to Tavares Filho et al. (1999) and Neves et al. (2003). Structural units: general term used to replace aggregates $(0-10 \mathrm{~cm})$ and/or clumps $(>10 \mathrm{~cm})$.

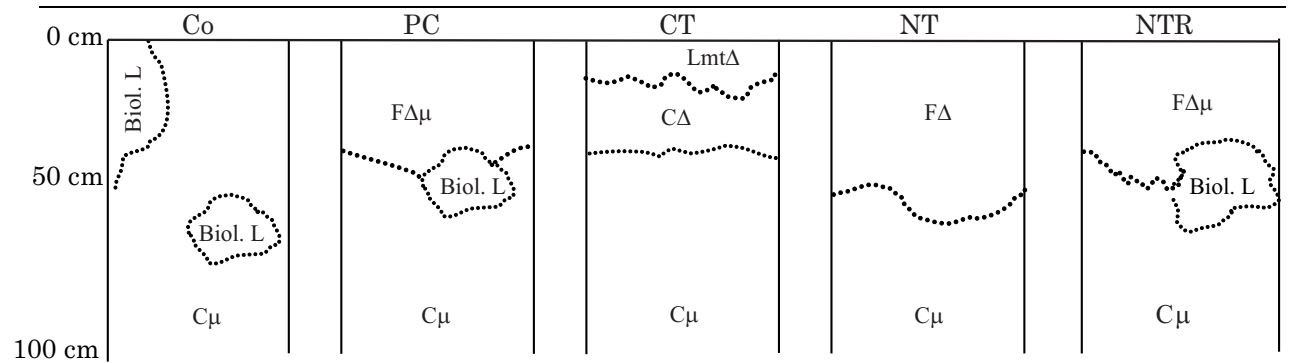

Figure 1. Representative drawing of the organizational mode of the structural units (Biol.L, L, C, F) and the internal state of the structural units $\mu, \Delta \mu$ and $\Delta$, which constitute the different morphologically homogeneous structural units indicated by the crop profile analysis of the Red Latosols under native forest and the different management systems. Co: control (native forest), PC: perennial crop, CT: conventional tillage, NT: no-tillage cultivation, NTR: no-tillage crop rotation, Biol.L: biological activity, $\mathrm{C} \mu$ : continuous non-compacted, F $\Delta \mu$ : Fragmented cracked (fissures) with intermediate compaction level; Lmt $\Delta$ : medium-sized loose clumps, compacted, C $\Delta$ : continuous compacted, F $\Delta$ : Fragmented cracked (fissures) compacted. 
oxygen diffusion and greater humidity in soils with better structure (greater infiltration and water availability). These factors facilitate root growth and promote better soil quality with increased plant growth and fewer erosion problems.

\section{Soil properties in the anthropized soil profiles.}

The mean values of organic matter $(\mathrm{OM})$ and flocculation degree (FD) are shown in figure 2 . Regarding OM (Figure 2a), the values ranged from 0.71 (CT) to 3.33 (Co) dag kg ${ }^{-1}$. The OM content of Co differed from the other management systems. In addition, the $\mathrm{OM}$ content in $\mathrm{CT}$ differed from the other management systems, and NTR $=\mathrm{PC}$ and $\mathrm{PC}=\mathrm{NT}$. These results indicated that the OM content in the soil profile after 20 years of CT management was approximately five times lower than that in the soil profile under Co. However, in the other management systems, this difference was on average two to three times lower. In this study, the OM content decreased in the following order: $\mathrm{Co}=>\mathrm{NTR}=>\mathrm{PC}=>\mathrm{NT}=>\mathrm{CT}$.

These results agree with the findings of Figueiredo et al. (2008) and Calegari et al. (2013), who showed that soils under CT had lower OM contents than soils under native Cerrado. In addition, these authors indicated that OM increased with time in soil under no-tillage cultivation. According to Calegari et al. (2013), a no-tillage cultivation system will improve the soil chemical properties and increase the total and microbial organic carbon down to $20 \mathrm{~cm}$ deep. Furthermore, the lowest OM content in the CT management system probably resulted from soil tillage because plowing and harrowing incorporate $\mathrm{OM}$ into the soil, which accelerates $\mathrm{OM}$ oxidation and decomposition (Neves et al., 2007; Portella et al., 2012; Llanillo et al., 2013; Calegari et al., 2013).

The FD (Figure $2 \mathrm{~b}$ ) values ranged from 53 (CT) to $93 \%$ in C. The FD in the CT management system differed from $\mathrm{C}$ and from all other management systems. Among the management systems, NTR = $\mathrm{PC}$ and $\mathrm{PC}=\mathrm{NT}$. These results indicated that aggregation in the soil with $\mathrm{CT}$ was 1.75 times lower in C, 1.58 times lower in PC and NTR and 1.34 times lower in the NT system after 20 years of uninterrupted management. This result indicates that soil aggregation is sensitive to the management applied over time (i.e., the greater the soil disturbance, the greater is disaggregation and vice versa).

In this study, soil aggregation decreased in the following order: $\mathrm{Co}=>\mathrm{NTR}=>\mathrm{PC}=>\mathrm{NT}=>\mathrm{CT}$ (i.e., in conventional planting, the breaking of aggregates resulting from soil tillage was accelerated and loss of organic carbon occurred due to $\mathrm{OM}$ oxidation (Mendonça \& Rowell, 1994). However, in no-tillage or perennial crop systems, the crop residues left on the surface contribute to higher OM concentrations and improve soil aggregation, compared to CT (Carpenedo \& Mielniczuk, 1990).
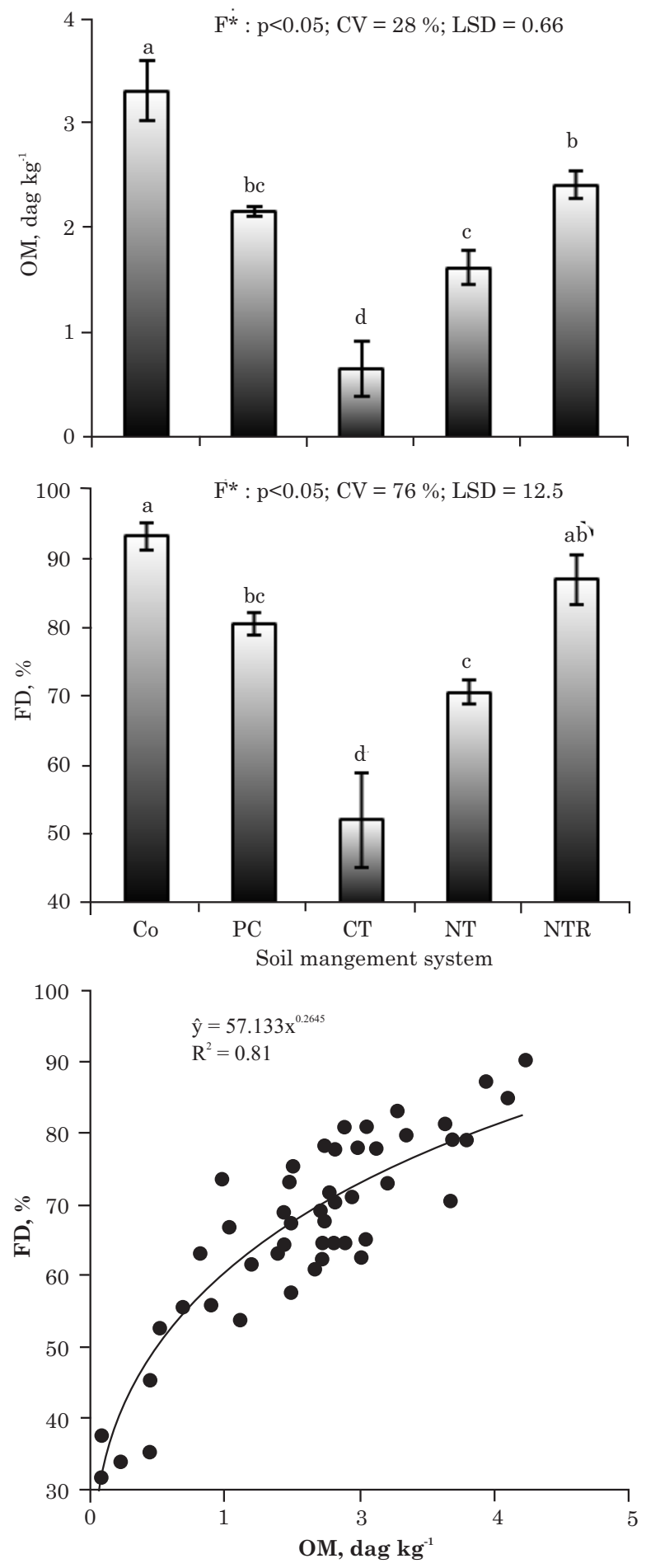

Figure 2. Mean values (mean of 10 samples/profile/ management system) and $5 \%$ confidence intervals for organic matter (OM) (a) and the flocculation degree (FD) (b) of a Red Latosol with native forest (Co-control) and with different management systems (PC: perennial crop, CT: conventional tillage; NT: no-tillage without crop rotation; NTR: no-tillage crop rotation) and the relationships between the $O M$ and $F D$ values (c). Means followed by the same uppercase letter do not differ according to the Tukey's test at $5 \%$. 
The distributions of the mean $\mathrm{OM}$ and FD values were similar (Figure 2a, b), indicating a good correlation between them (Neves et al., 2007; Calegari et al., 2013), which was confirmed by figure 2 c. Figure $2 \mathrm{c}$ shows a power regression curve with a $\mathrm{R}^{2}=0.81$. This regression curve indicates that the $\mathrm{OM}$ variations affected the mean FD values significantly. Thus, for the model used in this study, OM explained $81 \%$ of the FD variance in the soils under the different management systems. This result agrees with the findings of Cruz et al. (2003) and Calegari et al. (2013), who indicated that $\mathrm{OM}$ is a primary stabilizing agent for soil aggregates. According to Edwards \& Bremner (1967) and Tisdall \& Oades (1982), OM plays an important role in the formation and stabilization of soil aggregates by connecting organic polymers to inorganic surfaces through polyvalent cation bridges.

The stability of macroaggregates (diameter $>0.25 \mathrm{~mm}$ ) is related to microbial activity and the labile SOM fraction. In contrast, the stability of microaggregates (diameter $<0.25 \mathrm{~mm}$ ) is related to the surface characteristics of the soil particles. Furthermore, the main agents that are responsible for aggregation are $\mathrm{Al}$ and $\mathrm{Fe}$ oxides and stable $\mathrm{OM}$. Consequently, the microaggregates are affected by soil management practices (Tavares Filho, 1995; Soprano, 2002; Azevedo \& Bonumá, 2004). Therefore, high soil Fe polymer concentrations must be considered when evaluating the structural stability of the soil due to the disaggregation resulting from mechanical soil tillage. In addition to affecting macroaggregates, tillage is likely to affect the connections of these polymers to clay flakes. When combined with an ultradessication process (Chauvel \& Pedro, 1978; Chauvel et al., 1978), these effects may affect the structural stability of the macroaggregates.

The greatest confidence interval observed for the $\mathrm{CT}$ management system regarding $\mathrm{OM}$ and FD (Figure 2 a,b) was correlated with the soil morphological characteristics presented above (Figure 1). This correlation occurred because the two MOrgs (L and C), two ISs $(\Delta$ and $\mu$ ) and three MHUs (Lmt $\Delta$, $\mathrm{C} \Delta$ and $\mathrm{C} \mu$ ) in this management system were described with different aggregate sizes. Because soil was sampled at depths between 0 and $50 \mathrm{~cm}$, the differences in the profile organization were considered indirectly in the highest confidence interval, reinforcing the description.

The mean $\mathrm{Bd}$ and $\mathrm{Ma}$ are shown in figure 3. For $\mathrm{Bd}$ (Figure 3a), values ranged from 1.02 [forest (Co)] to $1.58 \mathrm{~kg} \mathrm{dm}^{-3}[\mathrm{NT}]$. The $\mathrm{Bd}$ value from the $\mathrm{C}$ differed from the values that were obtained for the management systems. In addition, there were no differences among the management systems. The Bd value was 1.55 times greater in the NT system than in Co and 1.14 times greater than the mean value observed in the other management systems.

Macroporosity (Figure 3b) varied from 0.11 (NT) to $0.30 \mathrm{~m}^{3} \mathrm{~m}^{-3}(\mathrm{Co})$. The Ma values of Co differed from
Ma in the other management systems. Among the management systems, $\mathrm{SRD}=\mathrm{PC}$ and $\mathrm{PC}=\mathrm{CT}=\mathrm{NT}$. The mean Ma in NT was 2.73 times lower than for $\mathrm{C}$ and 1.91 times lower than in NTR $\left(0.21 \mathrm{~m}^{3} \mathrm{~m}^{-3}\right)$. In this study, Ma decreased in the following order: Co $=>\mathrm{NTR}=>\mathrm{PC}=>\mathrm{CT}=>\mathrm{NT}$. As demonstrated by the $\mathrm{OM}$ and FD contents (Figure 2), $\mathrm{Bd}$ and $\mathrm{Ma}$ (Figure 3) had the greatest confidence interval in the CT system, in agreement with the description above (Figure 1) based on the visual evaluation of soil morphology.

These results confirmed the visual evaluation of soil morphology (Figure 1), according to which the management systems $\mathrm{CT}$ and NT resulted in IS of $\Delta$ (compacted with no visible porosity and with little or no root colonization). The systems PC and NTR resulted in IS of $\mu \Delta$ (intermediate compaction level). The Bd values were observed in areas with clayey Latosols in the $\mathrm{C}$ and intensive cultivation systems (Richart et al., 2005; Llanillo et al., 2006), confirming that machinery traffic on the soil surface can affect $\mathrm{Bd}$, regardless of the management. This effect can be more or less pronounced, according to the management system (Costa et al., 2006; Tavares Filho et al., 2012). In this study, Bd increased in the following order: $\mathrm{Co}=>\mathrm{NTR}=>\mathrm{PC}=>\mathrm{CT}=>\mathrm{NT}$.

The increased density in the NT system in comparison with Co can be most likely ascribed to the soil structuring when exposed to relatively heavy machinery traffic at inadequate moisture conditions (Costa et al., 2006; Figueiredo et al., 2008; Tavares Filho et al., 2012). This increase in Bd is usually offset by an increase in the OM content, Biol.L and soil aggregation (Figueiredo et al., 2008), resulting in better physical conditions than in other management systems (Tavares Filho et al., 2012). This process probably occurred in the NTR system where Biol.L was observed (Figure 1). According to Tavares Filho et al. (2003), Portella et al. (2012) and Llanillo et al. (2006; 2013), the presence of different root types (rotation of different crops in the same area) can help improve the soil structure, decrease $\mathrm{Bd}$ and increase soil organic matter aggregation.

In addition, Reinert et al. (2001) proposed 1.45 $\mathrm{kg} \mathrm{dm}^{-3}$ as critical $\mathrm{Bd}$ value for the characterization of horizons with clayey soil texture (over $550 \mathrm{~g} \mathrm{~kg}^{-1}$ ) as compacted. Thus, after 20 years of continuous use with the same management system, only in NT the BD values $\left(1.58 \mathrm{~kg} \mathrm{dm}^{-3}\right)$ indicated compaction and could restrict plant root growth and development. This result corresponds with findings of Richart et al. (2005), Llanillo et al. (2006), Araújo et al. (2007), Figueiredo et al. (2008) and Tavares Filho et al. (2012), who reported compaction in NT systems.

Regarding the mean $\mathrm{Bd}$ (Figure 3a) and $\mathrm{Ma}$ (Figure $3 b$ ) values, Ma was inversely related to $\mathrm{Bd}$. In figure $3 \mathrm{c}$, a good correlation was observed between $\mathrm{Ma}$ and $\mathrm{Bd}$ (as demonstrated by a thirdorder polynomial curve, with a $R^{2}=0.71$ ). This 

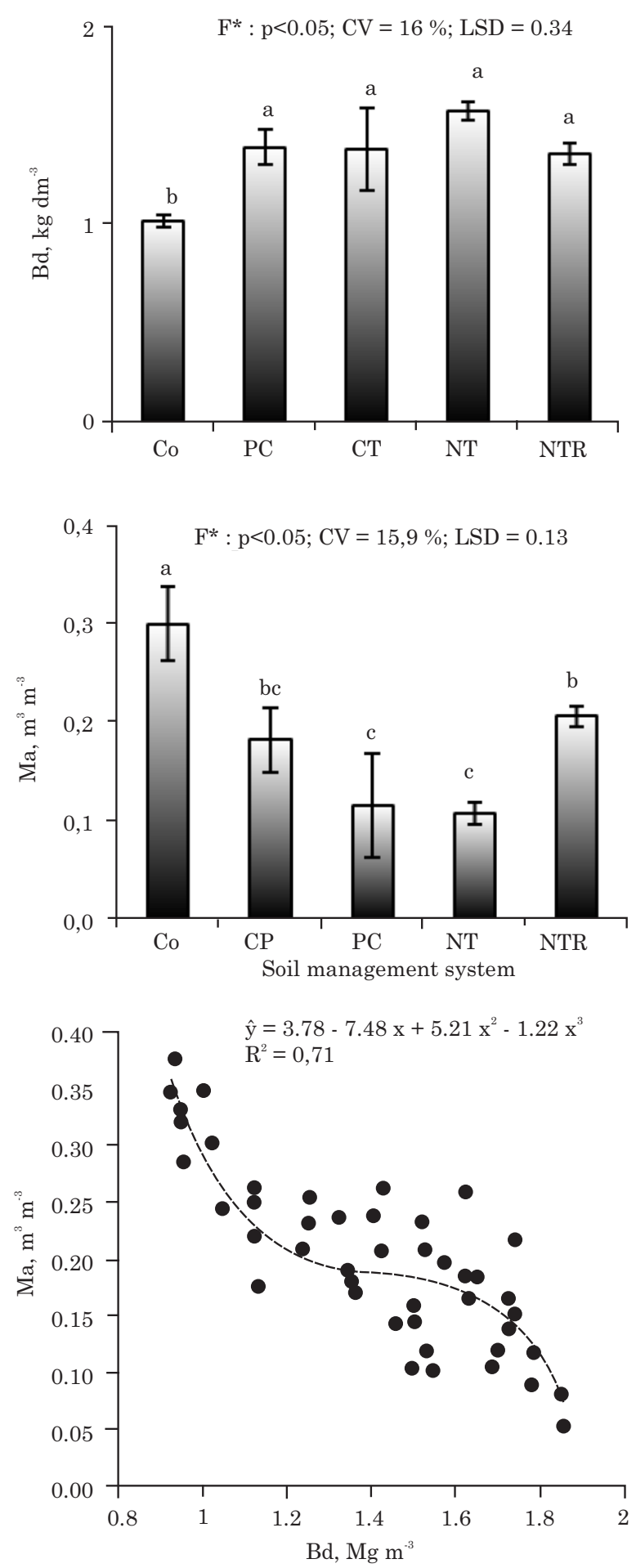

Figure 3. Mean values (mean of 10 samples/profile/ management system) and $5 \%$ confidence intervals for density (Bd) (a) and macroporosity (Ma) of a Red Latosol soil (b) under native forest (Cocontrol) and different management systems (PC: perennial crop, CT: conventional tillage, NT: notillage without crop rotation NTR: no-tillage crop rotation ) and the relationships between $\mathrm{Bd}$ and Ma (c). Means followed by the same uppercase letters do not differ by Tukey's test at $5 \%$. correlation indicated that the variations in $\mathrm{Bd}$ significantly affected the Ma values. Therefore, the variable $\mathrm{Bd}$ explained $71 \%$ of the variance in $\mathrm{Ma}$ in the model used for the soils under the different management systems, in agreement with findings of Neves et al., (2007), Figueiredo et al. (2008), Tavares Filho et al. (2012), Portella et al. (2012) and Llanillo et al. (2013).

In this study, the mean density in the $0-50 \mathrm{~cm}$ layer increased from $1.02 \mathrm{~kg} \mathrm{dm}^{-3}$ (forest) to $\sim 1.38$ $\mathrm{kg} \mathrm{dm}^{-3}$ (NTR and PC), $1.40 \mathrm{~kg} \mathrm{dm}^{-3}$ (CT) and 1.58 $\mathrm{kg} \mathrm{dm}^{-3}(\mathrm{NT})$. In addition, Ma decreased at the same times and depths, from $0.30 \mathrm{~m}^{3} \mathrm{~m}^{-3}$ (forest) to 0.21 $\mathrm{m}^{3} \mathrm{~m}^{-3}$ (NTR), $0.18 \mathrm{~m}^{3} \mathrm{~m}^{-3}$ (PC) and $0.11 \mathrm{~m}^{3} \mathrm{~m}^{-3}$ (CT and NT). Therefore, between Co and the different management systems, Ma decreased from $0.09 \mathrm{~m}^{3} \mathrm{~m}^{-3}$ in the NTR, to $0.12 \mathrm{~m}^{3} \mathrm{~m}^{-3}$ in the PC and $0.19 \mathrm{~m}^{3} \mathrm{~m}^{-3}$ in the $\mathrm{CT}$ and NT management systems. An increase in $\mathrm{Bd}$ reduces soil porosity (mainly $\mathrm{Ma}$ ) by an order of $0.01 \mathrm{~m}^{3} \mathrm{~m}^{-3}$ in the soil pore volume, which corresponds to a decrease of $10 \mathrm{~m}^{3} \mathrm{Mg}^{-1}$ in the total number of soil pores (Tavares Filho et al., 2010, 2012; Baquero, et al., 2012). Therefore, for a soil volume of 1 ha to a depth of $0.20 \mathrm{~m}$, the macropores were reduced by $7.20 \mathrm{~m}^{3}$ $\mathrm{ha}^{-1}$ in the NTR and PC management systems, by $7.60 \mathrm{~m}^{3} \mathrm{ha}^{-1}$ in the CT management system and by $11.20 \mathrm{~m}^{3} \mathrm{ha}^{-1}$ in the NT management system, compared to Co.

A Ma of more than $0.10 \mathrm{~m}^{3} \mathrm{~m}^{-3}$ is required for gas exchange and root growth of upland crops. The Ma data indicated that the $\mathrm{CT}$ and $\mathrm{NT}$ were very close to this limit $(10 \%)$, which suggested that these areas were already affected by limited plant growth. This reinforced previous results that showed how management strategies involving the use of increasingly larger machines without considering the soil moisture content or without crop rotation facilitate short and long-term compaction (Silva et al., 2000; Tavares Filho et al., 2010, 2012; Baquero et al., 2012; Llanillo et al., 2006, 2013).

This idea is reinforced in the radial graphs for the proportional values for the $0-50 \mathrm{~cm}$ layer for $\mathrm{OM}, \mathrm{FD}$, $\mathrm{Bd}$ and $\mathrm{Ma}$ (Figure 4). These results allow an overall view of soil quality under different soil management systems.

Differences were observed between the studied soil properties of Co and the management systems. By comparing the areas highlighted in the radial diagram (Figure 4), the degradation (from lowest to highest) is ranked as follows: $\mathrm{Co}=>$ [NTR $\leftrightarrow \mathrm{PC}$ (similar areas)] $=>\mathrm{NT}=>\mathrm{CT}$. In all studied management systems, $\mathrm{OM}$ and $\mathrm{Ma}$ were always below the $\mathrm{C}$ values and $\mathrm{Bd}$ was always higher than the $\mathrm{C}$ value. For the management systems NTR and PC, the FD was proportionally equal to the reference value.

The CT management system had clearly lower $\mathrm{OM}, \mathrm{FD}$ and $\mathrm{Ma}$ and higher Bd values than Co. This finding agrees with results of Silva et al. (2000) but disagrees with the findings of Silveira et al. (1999) 
and Silveira Neto et al. (2006). In addition, these results reinforce the fact that more intensive soil tillage and equipment traffic on the soil surface (especially under inadequate moisture conditions with increased OM degradation on the soil surface) results in greater soil degradation (Neves et al., 2007; Tavares Filho et al., 2010, 2012; Baquero et al., 2012; Llanillo et al., 2006, 2013; Calegari et al., 2013).

The comparison (Figure 4) between the NTR and NT without crop rotations is important. The NT management system is similar to the CT management system, but with higher $\mathrm{Bd}$ and lower Ma values (typical of compacted MHU ( $\Delta$ ) - Figure 1), compared to the other management systems. These differences indicated a considerable change in soil structure due to the continuous NT system. In contrast, the importance of crop rotations has been demonstrated. The crop rotations most likely helped to preserve the studied soil properties (OM, FD, Bd, and Ma). This result agrees with findings of Stone \& Silveira (2001) and Tavares Filho et al. (2012), who reported that crop rotations with the inclusion of species with aggressive root systems and high dry matter inputs could improve a soil's physical properties. In addition, the authors observed that Bd in NT soil can decrease
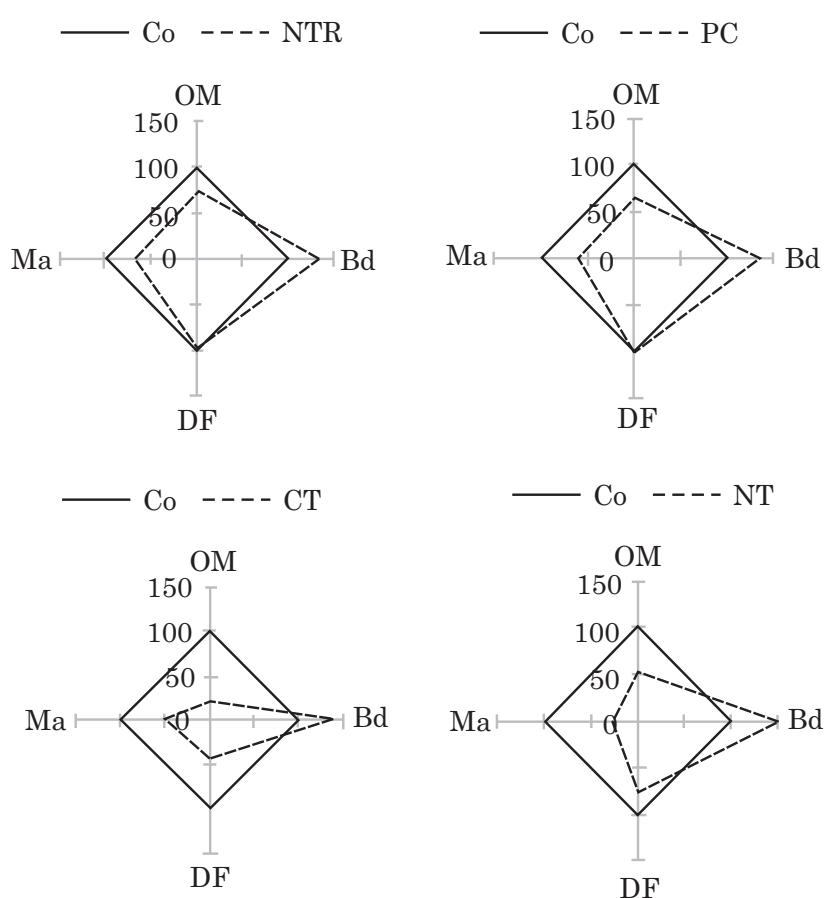

Figure 4. Comparative radial diagrams of the soil quality under the different management systems (NTR: no-tillage crop rotation; PC: perennial crop; CT: conventional tillage and NT: no-tillage without crop rotation ), considering the values obtained for the layer of $0-50 \mathrm{~cm}$ of soil organic matter content (OM), bulk density (Bd), degree of soil flocculation (FD) and soil macroporosity (Ma). with time due to increased $\mathrm{OM}$ in the surface layer, which would improve the soil structure.

\section{CONCLUSIONS}

1. Structural changes were observed to depths of $50 \mathrm{~cm}$, with predominance of $\Delta \mu$ structural units (intermediate compaction) in the PC and NTR systems. In addition, $\Delta$ structural units (compacted) were dominant in the $\mathrm{CT}$ and no-tillage cultivation systems.

2. Soil degradation increased in the following order: $\mathrm{Co}=>\mathrm{NTR}=>\mathrm{PC}=>\mathrm{NT}=>\mathrm{CT}$.

3. In all management systems, organic matter and macroporosity values were lower and bulk density higher than in the control treatment (native forest soil). In addition, the flocculation degree was proportionally equal to the reference value (forest) in the NTR and PC management systems.

\section{ACKNOWLEDGEMENTS}

We acknowledge the scholarships of scientific initiation of the last two authors of the study granted by the Brazilian Council for Scientific and Technological Development (CNPq) and Foundation Araucaria (Fundação Araucária).

\section{LITERATURE CITED}

ARAÚJO, R.; GOEDERT, W.J. \& LACERDA, M.P.C. Qualidade de um solo sob diferentes usos e sob cerrado nativo. R. Bras. Ci. Solo, 31:1099-1108, 2007.

AZEVEDO, A.C. \& BONUMÁ, A.S. Partículas coloidais, dispersão e agregação em Latossolos. Ci. Rural, 34:609 $617,2004$.

BAQUERO, J.E.; RALISCH, R.; MEDINA, C.C.; TAVARES FILHO, J. \& GUIMARÃES, M.F. Soil physical properties and sugarcane root growth in a Red Oxisol. R. Bras. Ci. Solo, 36:63-70, 2012.

CALEGARI, A.; CASTRO FILHO, C.; TAVARES FILHO, J.; RALISCH, R. \& GUIMARÃES, M.F. Melhoria da agregação do solo através do sistema plantio direto. Semina: Ci. Agron., 27:147-158, 2006.

CALEGARI, A.; TOURDONNET, S.; TESSIER, D.; RHEINHEIMER, D.S.; RALISCH, R.; HARGROVE, W.; GUIMARÃES, M.F. \& TAVARES FILHO, J. Influence of soil management and crop rotation on physical properties in a long-term experiment in Paraná, Brazil. Commun. Soil Sci. Plant Anal., 44:2019-2031, 2013. 
CARPENEDO, V. \& MIELNICZUK, J. Estado de agregação e qualidade de agregados de Latossolos Roxos, submetidos a diferentes sistemas de manejo. R. Bras. Ci. Solo, 14:99-105, 1990.

CHAUVEL, A.; BOCQUIER, A. \& PÉDRO, G. La stabilité et la transformation de la microstructure des sols rouges ferrallitiques de Casamance (Senegal). In: WORKING MEETNG ON SOIL MICROMORPHOLOGY, 5., Granada, 1978. Proceeding... Granada, 1978. 779-813p.

CHAUVEL, A. \& PÉDRO, G. Sur l'impotance de l'extrême dissiccation des sols (ultra-dessiccation) dans l'evolution pédologique des zones tropicales à saisons contrastées. C.R. Acad. Sc. t-286:1581-1584, 1978.

COLLARES, G.L.; REINERT, D.J.; REICHERT, J.M. \& KAISER, D.R. Qualidade física do solo na produtividade da cultura do feijoeiro num Argissolo. Pesq. Agropec. Bras., 41:1663-1674, 2006.

COSTA, E.A.; GOEDERT, W.J. \& SOUSA, D.M.G. Qualidade de solo submetido a sistemas de cultivo com preparo convencional e plantio direto. Pesq. Agropec. Bras., 41:1185-1191, 2006.

CRUZ, A.C.R.; PAULETO, E.A.; FLORES, C.A. \& SILVA, J.B. Atributos físicos e carbono orgânico de um Argissolo Vermelho sob sistemas de manejo. R. Bras. Ci. Solo, 27:1105-1112, 2003.

EDWARDS, A.P. \& BREMNER, J.M. Microaggregates in soils. J. Soil Sci., 18:64-73, 1967.

EMPRESA BRASILEIRA DE PESQUISA AGROPECUÁRIA EMBRAPA. Serviço Nacional de Levantamento e Conservação de Solo. Manual de métodos de análise de solo. Rio de Janeiro, Ministério da Agricultura, 1997. 212p.

FIGUEIREDO, C.C.; RAMOS, M.L.G. \& TOSTES, R. Propriedades físicas e matéria orgânica de um Latossolo Vermelho sob sistemas de manejo e cerrado nativo. Biosci. J., 24:24-30, 2008.

INSTITUTO AGRONÔMICO DO PARANÁ - IAPAR. Cartas Climáticas do Paraná. 2000. Available at: <http:// www.iapar.br/cartas climáticas do Paraná>. Accessed: Sept. 19, 2012

LEPRUN, J.C. Effets de la mise en culture sur la dégradation physique des sols. Bilan du ruissellement et de l'erosion de quelques grands écosystèmes brésiliens. Étude Gest. Sols, 1:45-65, 1994.

LLANILLO, R.F.; GUIMARÃES, M.F. \& TAVARES FILHO, J. Morfologia e propriedades físicas de solo segundo sistemas de manejo em culturas anuais. R. Bras. Eng. Agríc. Amb., 17:524-530, 2013.

LLANILLO, R.F.; RICHART, A.; TAVARES FILHO, J.; GUIMARÃES, M.F. \& FERREIRA, R.R.M. Evolução de propriedades físicas do solo em função dos sistemas de manejo em culturas anuais. Semina: Ci. Agron., 27:205$220,2006$.

MENDONÇA, E.S. \& ROWELL, D.L. Dinâmica do alumínio e de diferentes frações orgânicas de um Latossolo Argiloso sob cerrado e soja. R. Bras. Ci. Solo, 18:295-303, 1994.
NEVES, C.S.V.J.; FELLER, C.; GUIMARÃES, M.F.; MEDINA,C.C.; TAVARES FILHO, J. \& FORTIER, M. Soil bulk density and porosity of homogeneous morphological units identified by the cropping profile method in clayey Oxisols in Brazil. Soil Till. Res., 71:109-119, 2003.

NEVES, C.M.N.; SILVA, M.L.N.; CURI, N.; CARDOSO, E.L.; MACEDO, R.L.G.; FERREIRA, M.M. \& SOUZA, F.S. Atributos indicadores da qualidade do solo em sistema agrossilvopastoril no noroeste do estado de Minas Gerais. Sci. For., 74:45-53, 2007.

PORTELLA, C.M.R.; GUIMARÃES, M.F.; FELLER, C.; FONSECA, I.C.B. \& TAVARES FILHO, J. Soil aggregation under different management systems. R. Bras. Ci. Solo, 36:1868-1877, 2012.

RALISCH, R.; MIRANDA, T.M.; OKUMURA, R.S.; BARBOSA, G.M.C.; GUIMARÃES, M.F.; SCOPEL, E. \& BALBINO, L.C. Resistência à penetração de um Latossolo VermelhoAmarelo do Cerrado sob diferentes sistemas de manejo. R. Bras. Eng. Agríc. Amb., 12:381-384, 2008.

REINERT, D.J.; REICHERT, J.M. \& SILVA, V.R. Propriedades físicas dos solos em sistemas de plantio direto irrigado. In: CARLESSO, R.; PETRY, M.T.; ROSA, G.M. \& CERETTA, C.A., eds. Irrigação por aspersão no Rio Grande do Sul. Santa Maria, Palloti, 2001. 156p.

RICHART, A.; TAVARES FILHO, J.; BRITO, O.R.; LLANILLO, R.F. \& FERREIRA, R. Compactação do solo: causas e efeitos. Semina: Ci. Agron., 26:315-338, 2005.

RÓS, A.B.; TAVARES FILHO, J.; BARBOSA, G.M.C. Propriedades físicas de solo em diferentes sistemas de preparo para o cultivo da batata-doce. Semina: Ci. Agron., $35: 227-238,2014$.

SILVA, M.L.N.; CURI, N. \& BLANCANEAUX, P. Sistemas de manejo e qualidade estrutural de Latossolo Roxo. Pesq. Agropec. Bras., 35:2485-2492, 2000.

SILVEIRA NETO, A.N.; SILVEIRA, P.M.; STONE, L.F.F. \& OLIVEIRA, L.F.C. Efeitos de manejo e rotação de culturas em atributos físicos do solo. Pesq. Agropec. Trop., 36:29$35,2006$.

SILVEIRA, P.M.; SILVA, J.G.; STONE, L.F. \& ZIMMERMANN, F.J.P. Alterações na densidade e na macroporosidade de um Latossolo Vermelho-Escuro causadas pelo sistema de preparo do solo. Pesq. Agropec. Trop., 29:145-149, 1999.

SOPRANO, E. Estabilidade de agregados e dispersão de argila em função da calagem. Porto Alegre, Universidade Federal do Rio Grande do Sul, 2002. 106p. (Tese de Doutorado)

STONE, L.F. \& SILVEIRA, P.M. Efeitos do sistema de preparo e da rotação de culturas na porosidade e densidade do solo. R. Bras. Ci. Solo, 25:395-401, 2001.

TAMIA, A.; MOUREAU, R.; FORTIER, M. \& YORO, G. Influence du travail du sol sur l'évolution physique d'un sol forestier ferrallitique après défrichement motorisé. Étude Gestion Sols, 6:27-39, 1999.

TAVARES FILHO, J. \& TESSIER, D. Effects of different management systems on porosity of Oxisols in Paraná, Brazil. R. Bras. Ci. Solo, 34:899-906, 2010. 
TAVARES FILHO, J. Organisation et comportement des Latosols du Paraná (Brésil). Influence de leur mise en culture. Nancy, Université de Nancy I, 1995. 229p. (Tese de Doutorado)

TAVARES FILHO, J.; BARBOSA, G.M.C.; GUIMARÃES, M.F. \& FONSECA, I.C.B. Resistência do solo à penetração e desenvolvimento do sistema radicular do milho (Zea mays) sob diferentes sistemas de manejo em um Latossolo Roxo. R. Bras. Ci. Solo, 25:725-730, 2001.
TAVARES FILHO, J.; GUIMARÃES, M.F.; CURMI, P. \& TESSIER, D. Physical properties of an Alfisol and no-till soybean yield. R. Bras. Ci. Solo, 36:253-260, 2012.

TAVARES FILHO, J.; RALISCH, R.; GUIMARÃES, M.F.; MEDINA, C.C.; BALBINO, L.C. \& NEVES, C.S.V.J. Método do perfil cultural para avaliação do estado físico de solos em condições tropicais. R. Bras. Ci. Solo, 23:393-399, 1999.

TISDALL, J.M. \& OADES, J.M. Organic matter and waterstable aggregates in soils. J. Soil Sci., 33:141-163, 1982. 